\title{
A COMPARATIVE ANALYSIS OF THE SPECIAL LIMITATIONS TO PARTY AUTONOMY IN NON- CONTRACTUAL OBLIGATION IN EU AND CHINA
}

\author{
Jianhua Sun*
}

\begin{abstract}
This paper will offer a comparative analysis of the special Limitations to party autonomy in non-contractual obligation in European Union (EU) and China. There are a number of aspects that will be researched such as the type provisions which are providing from both legislations. The study will analyze the legislative provisions, the range of the non-contractual obligation and the type of limitations faced. For a while now, party autonomy has been viewed as the most important principle in conflict laws, and party autonomy could mirror the substantive principle of freedom in many areas of private international law. Furthermore, the recent scope extension from contracts to torts, succession has made significant contributions to this research. The above mentioned is very important and will be discussed in great detail, so the study can make noteworthy contribution to this line of research. The latter part of the paper will look into the provisions which are made focusing on the objectives of Rome II, the inadequacies of lex loci delicti and also the decline in dominance of lex loci delicti; thereafter an analysis of benefits and shortcomings will be given.
\end{abstract}

INTRODUCTION 400

I. WhAT ARE THE PROVISIONS OF BOTH LEGISLATIONS ...............................401

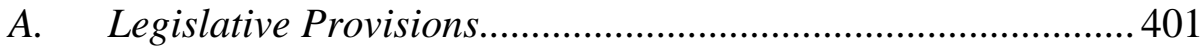

B. $\quad$ The Range of the Non-contractual Obligation ...........................403

C. What are the Limitations ............................................................404

II. WHY SUCH PROVISIONS ARE MADE ........................................................405

A. $\quad$ The Requirements of the Goal of Rome II ................................405

B. $\quad$ The Inadequacies of Lex Loci Delicti .........................................406

C. $\quad$ The Decline in Dominance of Lex Loci Delicti .......................... 407

III. WHAT THE BENEFITS AND SHORTCOMINGS OF SUCH REQUIREMENTS

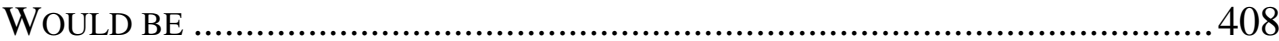

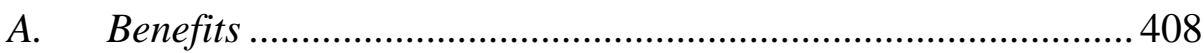

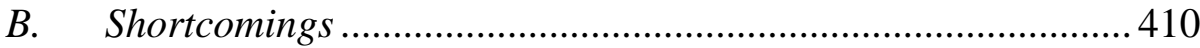

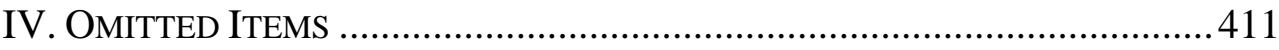

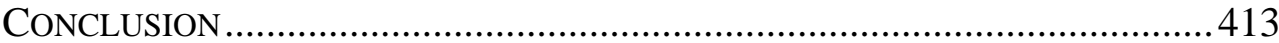

\footnotetext{
${ }^{*} \mathrm{PhD}$ Candidate, Institute of International Law, Wuhan University, China. Research fields: Private International Law, International Aviation Law.
} 


\section{INTRODUCTION}

It is no exaggeration to claim that, party autonomy has become the most important principle in conflict of laws. ${ }^{1}$ It is widely believed that, on the conflicts level, party autonomy could mirror the substantive principle of freedom in many areas of private law, ${ }^{2}$ particularly in contractual terms, but in recent years, its scope has been extended from contracts to torts, succession, ${ }^{3}$ matrimonial property, and, in some jurisdictions, even divorce and maintenance. ${ }^{4}$ In 2007, at the European Union, the Regulation 864/2007 on the law applicable to non-contractual obligations (Hereinafter Rome II) was passed. At the same time, the Law on the Application of Law for Foreign-Related Civil Legal Relationships of the People's Republic of China (Hereinafter LAL) was adopted by the Standing Committee of the National People's Congress on October 28, 2010, and entered into force on April 1, 2011. The LAL also stipulate the principle of party autonomy but is not same as the applicable conditions of some of the limitations in the contract. Even though the principle of part autonomy is provided in the noncontractual obligations, both these legislative provisions do not have the same restrictions and are not applied in the same field.

This article will firstly analyze two specific provisions of legislations, namely, Rome II Article 14 and LAL Articles 44 and 47. This is to clarify how the principles make provisions for the special limitations. Include the provision of legislation, the range of the non-contractual obligation, what are the limitations. Secondly, the author will interpret why the provision is made for that principle and what the principles and the limitation currently provides. Include the objectives of Rome II, the inadequacies of lex loci delicti and the decline in its dominance. Thirdly, the article will also analyze what the advantages and disadvantages are, but also determine what the limitations are. Fourth, the current legislations may have omissions and/or inadequacies that this article will take a look at. Lastly, the author will give recommendations on how China should improve the legislation on the specific issues discussed. For example, with reference to the limitations in

\footnotetext{
${ }^{1}$ Matthias Lehmann, Liberating the Individual from Battles between States: Justifying Party Autonomy in Conflict of Laws, 41 VAND. J. TRANSNAT'L L. 389 (2008).

${ }^{2}$ Friedrich K. Juenger, Appendix A: Letter from Friedrich Juenger to Harry C. Sigman, Esq., June 23, 1994, 28 VAN. J. TRANSNAT'L L. 445, 449 (1995).

${ }^{3}$ Cf. Art. 5 Hague Convention of August 1, 1989 on the law Applicable to Succession to the Estates of Deceased Persons; Arts. 90(2) and 91(2) Swiss Bundesgesez uber das International Privatrecht (IPRG); Art. 79 Belgian Wetboek van International Privaatrecht.

${ }^{4}$ A limited freedom of choice already exists in several EC Member State, and is also endorsed in the various drafts of the so-called 'Rome III Regulation' (more properly: the 'Brussels II-ter Regulation') and in the drafts of a Regulation on international maintenance obligations.
} 
contract and non-contractual obligations, one has to determine what the differences are with specific mention of time, explicit or implied, the choice of law is subject to public order and mandatory rules and other traditional restrictions. The restriction does not need formal requirements in China neither does the nature of the relationship between the parties. Requirements are only necessary for the tort, unjust enrichment and negotiorum gestio. The article also points out that, China did not bring these limitations and insufficiencies.

\section{What ARE THE PROVISIONS Of BOth LEGISLATIONS}

\section{A. Legislative Provisions}

In Rome II, the principle of party autonomy made provisions for limits in Art. $14^{5}$, whereas in China, provisions were mainly made in Arts. $44^{6}$ and $47^{7}$ of the LAL and is thus discussed below.

Art. 14 of Rome II from the time of infringement and to draw a distinction formulated from the past and projections for the future.

From the Article 14 of Rome II, we can see several limitations ${ }^{8}$, which may result in an application stricter than the national rules. To be more specific would be to consider from a time perspective, the difference between pre-dispute and post-dispute choice-of-law agreements for non-

\footnotetext{
${ }^{5}$ Rome II Art. 14:
}

(1) The parties may agree to submit non-contractual obligations to the law of their choice: (a) by an agreement entered into after the event giving rise to the damage occurred; or (b) where all the parties are pursuing a commercial activity, also by an agreement freely negotiated before the event giving rise to the damage occurred. The choice shall be expressed or demonstrated with reasonable certainty by the circumstances of the case and shall not prejudice the rights of third parties.

(2) Where all the elements relevant to the situation at the time when the event giving rise to the damage occurs are located in a country other than the country whose law has been chosen, the choice of the parties shall not prejudice the application of provisions of the law of that other country which cannot be derogated from by agreement.

(3) Where all the elements relevant to the situation at the time when the event giving rise to the damage occurs are located in one or more of the Member States, the parties' choice of the law applicable other than that of a Member State shall not prejudice the application of provisions of Community law, where appropriate as implemented in the Member State of the forum, which cannot be derogated from by agreement.

${ }^{6}$ LAL Article 44 Liability for violations of the laws, but often the parties have a common residence, and apply the common law of habitual residence. Violations occur, the parties agree to choose the applicable law, in accordance with their agreement.

${ }^{7}$ LAL Article 47 of unjust enrichment, and without a suitable agreement between the parties choose the applicable law. The parties do not select the applicable law of the habitual residence of the parties together; no common habitual residence places for unjust enrichment, and without a place in the law.

${ }^{8}$ See for an overview Th. M. de Boer, Party Autonomy and Its Limitations in the Rome II Regulation, 9 YEARbOOK of PRivate INTERNATIONAL LAW 22-29 (2007). 
contractual claims and allows enforcement of both, but subject to different restrictions ${ }^{9}$. Post-dispute agreements are enforced regardless of the identity of the parties, ${ }^{10}$ but pre-dispute agreements are enforced only if: (a) the parties are "pursuing a commercial activity"; ${ }^{11}$ (b) the agreement is "freely negotiated"; 12 and (c) the choice of law is "expressed or demonstrated with reasonable certainty by the circumstances of the case." 13

There were distinctions made in the above paragraphs concerning the Rome II dispute discussing the post-tort disputes and pre-tort disputes. From these limitations, we can see a big difference between pre-dispute and postdispute agreements under Rome II is that, pre-dispute agreements are enforceable only if the parties are engaging in 'commercial activity'. In all other respects, the two agreements are subject to the same restrictions, which are delineated by (a) the mandatory rules of a state in which "all the elements relevant to the situation ... are located" in fully-domestic cases; ${ }^{14}$ (b) the mandatory rules of Community law, in multistate intra-EU cases, ${ }^{15}$ Article 3(4) Rome I contains the same exception; and (c) the 'overriding' mandatory rules ${ }^{16}$ and the ordre public of the forum state in all cases. ${ }^{17}$

This difference leads to a pre-selection and choice of the parties after the different interests, but also shows the inadequacy of post-selection, but not a lot of pre-selection ban.

Post-tort agreements do have disadvantages, because after the occurrence of the tort, the parties are in a position to know of their rights and obligations, and have the opportunity to weigh the pros and cons of a choice-of-law agreement. This limitation aims at protecting the weaker party in relation to a future tort. Through Article 4(3), the law applicable to the connected contract may also with regard to weaker parties re-enter the scene, but in relation to this provision, the Explanatory Memorandum clarifies that, it may not harm weaker parties. ${ }^{18}$

\footnotetext{
${ }^{9}$ Rome II Art. 14 applies to all non-contractual claims other than those arising from unfair competition, restrictions to competition, and infringement of intellectual property rights. See Rome II, Arts. 6(4)) and 8(3). These exclusions mean that, choice-of-law agreements on these two subjects are unenforceable, regardless of whether they are entered into before or after the dispute. For discussions of Article 14, see T. De Boer, supra note 6; M. Zhang, Party Autonomy in Non-contractual Obligations: Rome II and Its Impacts on Choice of Law, 39 SETON HALL L. ReV. 861 (2009).

${ }^{10}$ Rome II, Art. 14(1)(a).

${ }^{11}$ Rome II, Art. 14(1)(b).

${ }^{12}$ Ibid.

${ }^{13}$ Ibid. Another requirement is that, the agreement "shall not prejudice the rights of third parties."

${ }^{14}$ Rome II, Art. 14(2).

${ }^{15}$ Rome II, Art. 14(3).

${ }^{16}$ Rome II, Art. 16.

${ }^{17}$ Rome II, Art. 26.

${ }^{18}$ Explanatory Memorandum to the 2003 Proposal, 13.
} 


\section{A COMPARATIVE ANALYSIS OF THE SPECIAL 403}

Therefore, these agreements need little policing by the legal system. ${ }^{19}$ In fact, the system benefits from these agreements insofar as they promote judicial economy. This is why many codifications such as the German and Belgian expressly sanction post-tort choice-of-law clauses. 20 Similar restrictions can be found in, e.g., the Swiss statutes on private international law. $^{21}$

Nonetheless, there are choice-of-law agreements that are of a more serious nature. Pre-tort choice-of-law agreements have more serious problems. Parties do and should not contemplate a future tort unless they have the relevant information, that will clarify details of the severity the injuries and they do not know who will injure them, or what will be the nature or severity of the injury. Moreover, a weak or unsophisticated party may uncritically sign such an agreement, even when the odds of him being the victim are much higher than the odds of his being the tortfeasor. ${ }^{22}$ For these and other reasons, most systems do not sanction pre tort agreements. ${ }^{23}$ For example, China did not provide pre-tort agreement.

Even though there are restrictions, there is still enough room for expanding the scope. The principle of party autonomy is far from being applicable to all fields of the law. Yet, its scope is increasingly extended and it is now applied in areas where it was unthinkable before. ${ }^{24}$ For example, there is the lack of negotiorum gestio and unjust enrichment etc.

However, in China, the provision can only be applied post-tort, which is then firstly followed by the application of an agreement choice, and secondly the law of common habitual residence and lastly the place of tort (unjust enrichment and negotiorum gestio).

\section{B. The Range of the Non-contractual Obligation}

As seen from the legislation, the scope is not the same specifically

\footnotetext{
${ }^{19}$ Symeon C. Symeonides, The American Revolution and the European Evolution in Choice of Law: Reciprocal Lessons, EleCtRONIC COPY 25. Available at http://ssrn.com/abstract=1104284.

${ }^{20}$ See, e.g., Egbgb Art. 42; Belgian Pil Code Art. 101; cf. Austrian Pil Act, § 35.

${ }^{21}$ Switzerland: Art. 132 IPRG. See also Th. M. de Boer, Party Autonomy and Its Limitations in the Rome II Regulation, 9 YEARBOOK OF PRIVATE INTERnATIONAL LAW 27 (2007).

${ }^{22}$ Symeon C. Symeonides, The American Revolution and the European Evolution in Choice of Law: Reciprocal Lessons, ElECTRONIC COPY 25-26. Available at http://ssrn.com/abstract=1104284.

${ }^{23}$ See, e.g., Egbgb, Art. 42 ("After the event giving rise to a non-contractual obligation has occurred, the parties may choose the law that shall apply to the obligation.") (emphasis added); Belgian Pil Code, accord. But see Dutch Pil Act, Art. 6 ("Where the parties have chosen the law applicable to any matter relating to tort, ... that law shall apply between them ...").

${ }^{24}$ See generally Symeon C. Symeonides, General Report, in Private International Law at the End of the 20th Century: Progress or Regress?, 1, 56-57 (1999) (giving examples of areas of law where party autonomy has not been previously applied).
} 
when compared to the Rome II, China has a more narrow scope. It did not provide pre-tort disputes and delict.

However, in Rome II, damage shall cover any consequence arising out of tort/delict, unjust enrichment, negotiorum gestio or culpa in contrahendo. ${ }^{25}$ This article points out the scope of Rome II and non-contract obligation. The principle of party autonomy in China, its scope of application compared to previous legislation has significantly expanded.

Nevertheless, if one studies the LAL, one discovers that, the doctrine of party autonomy has been widely applied, and is often the first resort for determining the applicable law in areas such as agency, ${ }^{26}$ trust, ${ }^{27}$ arbitral agreements, ${ }^{28}$ matrimonial property relationships, ${ }^{29}$ divorce by mutual consent, ${ }^{30}$ movables, ${ }^{31}$ general contracts, ${ }^{32}$ consumer contracts, ${ }^{33}$ post-tort disputes, ${ }^{34}$ unjust enrichment and negotiorum gestio, ${ }^{35}$ the transfer and licensing of IP rights, ${ }^{36}$ and post-infringement disputes arising out of IP rights. ${ }^{37}$ So we can see from the provisions that, China make its scope of the principle of party autonomy in non-contractual obligation: post-tort disputes, unjust enrichment and negotiorum gestio.

\section{What are the Limitations}

Just as seen in the law above, both legislations are subject to public order and mandatory rules, but there are differences. Firstly, with reference to time, China only make post-tort, but Rome II choice has also pre-tort. Secondly, the different applicable order of the various provisions in the absence of agreement, China opted to apply the law of common domicile, if there is no common domicile, the law of lex loci delicti (or the place of unjust enrichment and negotiorum gestio) will be applied.

\footnotetext{
${ }^{25}$ Rome II Art. 2(1).

${ }^{26}$ Article 16.

${ }^{27}$ Article 17.

${ }^{28}$ Article 18.

${ }^{29}$ Article 24.

${ }^{30}$ Article 26.

31 Article 37.

${ }^{32}$ Article 41.

${ }^{33}$ Article 42.

${ }^{34}$ Article 44.

${ }^{35}$ Article 47

${ }^{36}$ Article 49.

${ }^{37}$ Article 50.
} 


\section{Why SuCh PROVISIONS ARE MADE}

The principle of party autonomy in the contract and effective implementation fields are widely accepted principles of the conflict of law, that forms an important method of the choice of law, however, the field of traditional tort law in the selection is first applied to the lex loci delicti, this method of practice in the past that there are many problems and deficiencies which are often uncertain and cannot properly protect vulnerable parties, especially the rights of a party and the party's vulnerability can not always be protected. In 2007 at the European Union, the principle of party autonomy was introduced in the non-contractual obligation so that the principle applies to a broader scope. In 2010 in China, the LAL set the similar provisions and recognizes the application of the principle. The acceptance of such a legislation implied that, the legislation can make up for past deficiencies, balanced the relations of certainty, predictability and uniformity to promote the harmonious choice of applicable law. Recent legislation is mainly based on the following reasons.

\section{A. The Requirements of the Goal of Rome II}

Rome II is purposed to enhance the "compatibility of the rules applicable in the member states concerning the conflict of law(s)." ${ }^{\text {38 }}$ But Rome II has a stated focus on the "harmonization of conflict-of-law rules" with respect to non-contractual obligations. ${ }^{39}$ Aimed at helping attain legal certainty regarding the applicable law in non-contractual obligations, ${ }^{40}$ Rome II sets forth the choice of law rules that are required to be uniformly applied in the whole European Community "irrespective of the nature of the court or tribunal seized." ${ }^{41}$ But in this case, the harmony does not require uniformity. The lack of unity created a fair amount of uncertainty and therefore encouraged the so called "Forum Shopping".

One other reason, Most EU member states have long applied Sevigne's approach to choice of law and have codified these principles during the twentieth century in an effort to influence EU choice of law. ${ }^{42}$ Party autonomy is no longer merely a tool to determine the applicable law but an

\footnotetext{
${ }^{38}$ Rome II, at para. 2.

${ }^{39} I d$. at para. 4.

${ }^{40}$ Id. at para. 6 .

${ }^{41} \mathrm{Id}$. at para. 8.

${ }^{42}$ Ralf Michaels, The New European Choice-of-Law Revolution: Lessons for the United States?, 82 TUL. L. REV. 1621 (2008).
} 
instrument toward a competition among legal orders. ${ }^{43}$

In addition, the Regulation is an essential part of the EU's larger project on private international law, which also includes recognition and enforcement of judgments and choice of law for contractual obligations, to promote the functioning of the internal market and stem forum shopping. ${ }^{44}$

Rome II is bound to place such a premium on certainty because certainty is necessary to ensure uniformity. ${ }^{45}$ Uniform rules can increase predictability. In Recital 16, it is said that, uniform rules are expected to enhance the 'foreseeable of court decisions'. ${ }^{46}$ This can ensure a reasonable balance between the interests of the person claimed to be liable and the person who sustained damage. ${ }^{47}$

Uniform conflicts rules ensure the stability of cross-border legal relationships, they reduce the attraction of forum shopping, and they enable prospective litigants to predict the outcome of choice-of-law lawsuit. Not surprisingly decisional harmony is viewed as an ideal worth striving for, even on the level of national conflicts law.

\section{B. The Inadequacies of Lex Loci Delicti}

Defects in the previous method can be used for the following inadequate choice of law. Mounting criticism of the prevailing choice-oflaw method and its rigid, mechanical rules has led to innovations characterized by increased flexibility on the one hand, and a fresh orientation towards the policies of substantive law on the other. Naturally, these changes detract from the traditional ideal of decisional harmony: The achievement of uniform results is jeopardized both by flexible rules allowing a discretionary choice, and by rules inspired by substantive policies that may vary from state to state. ${ }^{48}$

It argues that, in past decades, choice of law in tort cases has experienced more dramatic change than any other areas in the conflict-oflaw area, but the transition from the single and territorially-based "place of

\footnotetext{
${ }^{43}$ Ralf Michaels, The New European Choice-of-Law Revolution: Lessons for the United States?, 82 TUL. L. REV. 1635 (2008).

${ }^{44}$ Rome II, Recital (7); at 6-7, COM (2003) 427 final (July 22, 2003).

${ }^{45}$ Clay H. Kaminsky, The Rome II Regulation: A Comparative Perspective on Federalizing Choice of Law, 85 Tul. L. ReV. 81 (2010).

${ }^{46}$ Th. M. de Boer, The Purpose of Uniform Choice of Law Rules: The Rome II Regulation, NETHERLANDS INTERNATIONAL LAW REVIEW 300 (LVI 2009).

${ }^{47}$ Th. M. de Boer, The Purpose of Uniform Choice of Law Rules: The Rome II Regulation, NETHERLANDS INTERNATIONAL LAW REVIEW 301 (LVI 2009).

${ }^{48}$ Th. M. de Boer, The Purpose of Uniform Choice of Law Rules: The Rome II Regulation, NETHERLANDS INTERNATIONAL LAW REVIEW 330 (LVI 2009).
} 


\section{A COMPARATIVE ANALYSIS OF THE SPECIAL 407}

wrong” rule to the multiple, as well as flexible, approaches posed great challenges to the certainty and predictability that, the modern conflict of law is driven to achieve. ${ }^{49}$

\section{The Decline in Dominance of Lex Loci Delicti}

It was widely recognized that, the lex loci delicti was applied to the tort and other fields concerning the tort for a long time. In the past decades, however, choice of law in non-contractual obligations has witnessed sweeping changes, particularly in the torts context. ${ }^{50}$ Since the 1960 's, the principle has undergone profound changes. In Babcock $v$. Jackson ${ }^{51}$, case of tort law was criticized a lot. Scholars have pointed out that, this principle is too mechanical, because without distinction to all violations by the dominance of tort law, it is not necessarily a reasonable result. This is because with the rapid development of modern transportation and communication, the place of tort and the place of conclusion in contract have a great chance.

For example, a citizen from country A travels by car to country B and has a car accident in country B. The accident was caused by a citizen of Country B. Therefore, the law of country B should be applicable to the accident that occurred and thus cannot be assumed as reasonable. In addition, some countries have linked cases and found that, the lex loci delicti are very difficult to determine. Furthermore, the tort implementation of the high sea or un-inhabitant place applying the lex loci delicti has no meaning. So scholars have put forward the law of tort , it's not only for the applicable law, you can also apply it to other laws such as the lex fori, the parties or the domicile of the nationality law of the land law, and the law of the place of the most significant relationship. To apply the law chosen by the parties is an option for a solution. As a result, territoriality still plays a role in shaping the choice-of-law rules for non-contractual obligations, but the dominance of territorially-based, traditional rules has become less and less of a phenomenon. $^{52}$

\footnotetext{
${ }^{49}$ Mo Zhang, Party Autonomy in Non-contractual Obligations: Rome II and Its Impacts on Choice of Law, 39 SeTON Hall L. ReV. 866 (2009).

${ }^{50}$ Russell J. Weintraub, COMmENTARY ON THE CONFLict OF LAWs 371 (5th ed. 2006) (“A territorial rule is one that selects a state's law without regard to the law's content but based on some contact that state has with the parties or the transaction.”).

${ }^{51} 12$ N.Y. 2d 473, 483 (1963).

${ }^{52}$ Symeon C. Symeonides, The American Revolution and the European Evolution in Choice of Law: Reciprocal Lessons, 82 TuL. L. REV. 1741, 1744-53 (2008).
} 


\section{WHAT THE BENEFITS AND SHORTCOMINGS OF SUCH REQUIREMENTS WOULD BE}

\section{A. Benefits}

In EU, extensive party autonomy (expressed in Rome II Art. 14) show the European legislature made judgments on the value of different rules and policies that may be characterized as liberal, progressive and openminded. ${ }^{53}$ The LAL in China has been widely applied in the principles involved in more traditional areas, which also shows that, China's open attitude to face the world, face modernization is future oriented. Party autonomy thus helps overcome the adverse effects for private relationships that are caused by the division of the world into multiple legal systems. ${ }^{54}$

The author thinks that, this principle is helpful to the application of non-contractual obligation. The argument is that of certainty and costavoidance. There are three aspects. First, it enables contracting parties to plan their transactions and conduct with reference to a single legal system. Secondly, it reduces the cost of dispute resolution in having all connected disputes resolved by a single system of law. Thirdly, it increases the probability of amicable settlements of disputes, if the disputants only need to bargain with reference to a single system of law which they had chosen in the first place. ${ }^{55}$ Specifically speaking, the reasons are as follows.

a. Helping resolve the dispute efficiently.

This is mainly reflected in: Firstly, the parties to negotiate options that dominate the tort law, the parties can expect tort cases dealing with the results. In the infringement occurred, the law chosen by the parties for more than one possible party, which is if the party has no choice, the court will give a comprehensive analysis of various factors to determine how the law should be applied to the case at hand. The parties have great uncertainty nature if allowed parties choose the law in the tort law applied. In tort law, it is applicable to a large extent. Secondly, the judges should be facilitated. The judge should not be involved in the infringement of each objective connection point, so the judge can directly allow the parties to choose the applicable law, and also to improve work efficiency so that the case can be resolved quickly.

b. Special restrictions would be needed to achieve the legislative policy

\footnotetext{
${ }^{53}$ Rome II, Arts. 7, 14.

${ }^{54}$ Matthias Lehmann, Liberating the Individual from Battles between States: Justifying Party Autonomy in Conflict of Laws, 41 VAND. J. TRANSNAT'L L. 408 (2008).

${ }^{55}$ YEO Tiong Min, The Effective Reach of Choice of Law Agreements, 20 SAcLJ 734 (2008).
} 


\section{A COMPARATIVE ANALYSIS OF THE SPECIAL 409}

to protect the weaker.

For curtained stability of the weaker and consumers, Rome II should also consider the rights of the beneficiaries, the manager and the profits in the unjust enrichment and negotiorum gestio made.

In EU and China, however, the critical question is whether this rule provides sufficient safeguards that, this newly-granted freedom will not be abused by the strong contracting parties. By limiting pre-dispute choice-oflaw agreements to situations in which all the parties are "pursuing a commercial activity”, Rome II seeks to protect certain presumptively weak parties, such as consumers, employees, and certain — but not all—individual insured's. This limitation, however, leaves exposed a whole host of small commercial actors, such as small businesses. ${ }^{56}$

Subsequently, Article 14 does not live up to the statement in Recital 32 that "protection should be given to weaker parties by imposing certain conditions on the choice." ${ }^{57}$ As with some other freedom-laden ideas, Article 14 may well become the vehicle for taking advantage of weak parties many of whom are parties to "commercial" relationships. ${ }^{58}$ China's legislation also reflects the interest of certain policies that protect the weaker. $^{59}$

c. In line with the principle of economic efficiency, reduce costs, promote judicial economy.

The principle of party autonomy in the application of non-contractual obligation have some benefits and convenience, but it must be emphasized that, the core values underlying the Shawinigan approach, in particular the reduction of transaction costs for the parties, coincide with the goal of efficiency promoted by economic analysis of law. ${ }^{60}$ Amongst other things, In the United States, Erin O'Hara and Larry Ribstein have made the case for an ex ante choice of law in torts based on considerations of efficiency. ${ }^{61}$ These arguments also support Article 14 of Rome II.

\footnotetext{
${ }^{56}$ Symeon C. Symeonides, Party Autonomy in Rome I and II from a Comparative Perspective, LIBER AMICORUM KURT SIEHR 546 (2010).

${ }^{57}$ Rome II, Recital (31).

${ }^{58}$ Symeon C. Symeonides, The American Revolution and the European Evolution in Choice of Law: Reciprocal Lessons, ELECTRONIC COPY 28. Available at http://ssrn.com/abstract=1104284.

${ }^{59}$ LAL Art. 42.

${ }^{60}$ Horatia Muir Watt, Choice of Law in Integrated and Interconnected Markets: A Matter of Political Economy, 9 Colum. J. EuR. L. 383, 387 n. 25 (2003) (arguing that, "[i] many cases ... economic analysis appears to reinvent the wheel, through insufficient attention to traditional conflicts theory"); Wiegand, supra note 179, at 25-26; see also Giesela Rühl, Methods and Approaches in Choice of Law: An Economic Perspective, 24 BERKELEY J. INT’L L. 801, 807-15, 818-25 (2006) (supporting the above hypothesis). On tort conflicts in particular, see Ralf Michaels,

${ }^{61}$ See Erin A. O’Hara \& Larry E. Ribstein, From Politics to Efficiency in Choice of Law, 67 U. CHI. L. REV. 1210 (2000).
} 
d. The principles in the process of using them under certain restrictions will be more conducive to achieving the original goals and objectives, so that the parties in the limited choice may resolve disputes in an effective and orderly, timely and reasonable expectation of the parties to protect the legitimate rights and interests. A very common theory holds that, the principle of party autonomy protects the reasonable expectations of the parties. ${ }^{62}$

e. The principle of party autonomy can also reduce the parties to limit the selection of the court, and can thus help the court make a reasonably fair decision. Generally speaking, there are three principal ways for the international community to reduce forum shopping: (i) harmonization of the applicable substantive rules; (ii) through rules on jurisdiction; and (iii) harmonization of the applicable PIL. ${ }^{63}$ Therefore, uniform rules of the choice of law in Rome II can promote harmony and strongly to avoid forum shopping.

\section{B. Shortcomings}

Uniform rules of the choice of law in promoting the harmony, but also bringing some negative factors to the party, mainly from the following aspects.

a. Uniform rules of the choice of law have shortcomings, as there were bound to be, both in coverage (e.g., defamation, media delicts) and in drafting that may lead to interpretative difficulties (e.g., with respect to quantification of damages and review of punitive damages). ${ }^{64}$ In fact, the victim's habitual residence connection opens a door to the "forum shopping", as it is easier for individuals to move or may be its change their habitual residence than for companies. In addition, most law-and-economics scholars find modern approaches to choice of law unpredictable, chaotic, ${ }^{65}$

\footnotetext{
${ }^{62}$ Edith Friedler, Party Autonomy Revisited: A Statutory Solution to a Choice-of-Law Problem, 37 U. KAN. L. ReV. 471 (1989); Robert A. Leflar, Choice-Influencing Considerations in Conflicts Law, 41 N.Y.U. L. Rev. 267, 283 (1966); Amos Shapira, Territorialism, National Parochialism, Universalism and Party Autonomy: How Does One Square the Choice-of-Law Circle?, 26 BRooK. J. InT'L L. 199, 203 (2000); see also Restatement (Second) of Conflict of Laws $\S 187 \mathrm{cmt}$. e (stressing the need for predictability); Weintraub, supra note 4, at 449 (same).

${ }^{63}$ Patrick L. Krauskopf \& Andrea Tkacikova, Competition Law Violations and Private Enforcement: Forum Shopping Strategies, 4(1) G.C.L.R. 35 (2011).

${ }^{64}$ Perter Hay, Contemporary Approaches to Non-contractual Obligations in Private International Law (Conflict of Laws) and the European Community's “Rome II" Regulation, 4 THE EUROPEAN LEGAL FORUM (E) 151 (2007).

${ }^{65}$ Richard A. Posner, The Problems of JuRisprudence 430 (1990) (decrying "the destruction of certainty in the field of conflict of laws as a result of the replacement of the mechanical common law rules by 'interest analysis”'); Andrew T. Guzman, Choice of Law: New Foundations, 90 GEo. L.J. 883, 893 (2002); See Erin A. O’Hara \& Larry E. Ribstein, From Politics to Efficiency in Choice of Law, 67 U. CHI. L. REv. 1164 (2000) (“[P] ublic policy inquiries thwart certainty and predictability.”).
} 
and prejudiced in favor of plaintiffs and forum law. ${ }^{66}$ Therefore, in China and the EU, the uniformed rules of choice of law are limited, and limit forum shopping is not completely restricted to the practice of the courts and the party's choose to circumvent the law.

b. It is regrettable that, Article 14 requires only minimal scrutiny. The only restriction it imposes on pre-tort agreements (that it does not impose on post-tort agreements) is that, it must be "freely negotiated" and that, the parties must be "pursuing a commercial activity". This is neither sufficient nor free of problems. ${ }^{67}$

However, that party cannot always predict the precise issue with regard to which a dispute may arise and thus cannot guarantee a favorable result under the chosen law. Even if that party is fortunate to obtain such a result, that result will of necessity disfavor the other party. ${ }^{68}$

c. Last but not the least, uniform rules of the choice of law opted to limit the time in the in specific areas and only in substantive law, while there was no limit on the other issues. So it should be pointed out that, the harmonization of choice of law rules will only stop forum shopping for substantive law advantages, not for procedural advantages. ${ }^{69}$

\section{OMITTED ITEMS}

China and the EU's principle of party autonomy are applied to extensive fields and expand the scope of application at the same time. There are appropriate restrictions that can be made, but these restrictions have not taken all the issues into account or made any relevant provisions. This was reflected in the following aspects:

(1) From a formal perspective, the principle of party autonomy when used in the contract is formal requirements, e.g., expressed or implied. But what appears unclear in Article 14(1) of Rome II is whether the choice must be made in writing or whether it could be made orally. LAL has also not made provision. However, given the importance of the choice of law, an

\footnotetext{
${ }^{66}$ Patrick J. Borchers, The Choice-of-Law Revolution: An Empirical Study, 49 WASH. \& LEE L. ReV. 357, 377 (1992) (stating that modern approaches favor forum law, recovery, and less clearly, residents); But cf. Stuart E. Thiel, Choice of Law and the Home-Court Advantage: Evidence, 2 Aм. L. \& ECON. Rev. 291 (2000).

${ }^{67}$ Symeon C. Symeonides, Rome II and Tort Conflicts: A Missed Opportunity, 56 AM. J. Comp. L. 216 (Winter 2008).

${ }^{68}$ Symeon C. Symeonides, ed., Private International Law at the End of the 20th Century: Progress or Regress?, KLUWER LAW INTERNATIONAL 39 (1999).

${ }^{69}$ James J. Fawcett, Declining Jurisdiction in Private International Law: Reports to the XIVth Congress of the International Academy of Comparative Law, AtHENs 22 (Oxford: Clarendon Press, August 1994).
} 
agreement in this regard would normally be made in writing. ${ }^{70}$

(2) The issues of the residence requirement are omitted. In view of this problem, it is unfortunate that, Rome II and LAL do not contain a provision stating that, if the parties are resident in different countries, but the law of those countries is the same as regards the point in issue, they will be treated as if they were resident in the same country. The Louisiana Civil Code has such a provision. ${ }^{71}$

(3) Whether the infringement of general rules can be ignored when the common rules of residence are forced in LAL Art. 44.

In addition, there is one other problem that is unclear when the law of the parties' common habitual residence applies, can one disregard the mandatory rules in the law of the place of the commission of the tort, or the law of the place where damage was sustained $?^{72}$ It is important to note that, the common-residence rule is most questionable when the rights of third parties are affected. ${ }^{73}$

(4) In adjusting the scope of legal relationship, should the party autonomy be taken a step further, and effect given to parties' choice of a law to govern non-contractual obligations connected to their contractual relationship $?^{74}$ This is not clearly defined in relevant provisions of the EU and China, so it was not conducive to appropriately and effectively solve the non-contractual choice of law issues, because it is not comprehensive and systematic enough.

(5) No researcher has argued why party autonomy is respected in the field of non-contract obligation, or why a choice by the Regulations uniform conflicts rules. At any rate, the preamble does not explain why the parties should be allowed to choose the law of a country, that is not in any way connected with the non-contractual obligation at issue. Such freedom of choice can only be understood if it is viewed as a transposition of the parties' power to dispose of their rights under substantive law to the level of conflicts law. ${ }^{75}$

\footnotetext{
${ }^{70}$ Mo Zhang, Party Autonomy in Non-contractual Obligations: Rome II and Its Impacts on Choice of Law, 39 SeTON Hall L. ReV. 893 (2009).

${ }^{71}$ Trevor C. Hartley, Choice of Law for Non-contractual Liability: Selected Problems under the Rome II Regulation, 57(4) I.C.L.Q. 901 (2008).

${ }^{72}$ Guangjian Tu, China's New Conflicts Code: General Issues and Selected Topics, 59 Aм. J. Comp. L. 583 (Spring 2011).

${ }^{73}$ Russell J. Weintraub, The Choice-of-Law Rules of the European Community Regulation on the Law Applicable to Non-contractual Obligations: Simple and Predictable, Consequences Based, or Neither?, 43 TEX. INT'L L.J. 408 (Summer 2008).

${ }^{74}$ YEO Tiong Min, The Effective Reach of Choice of Law Agreements, 20 SAcLJ 733 (2008).

${ }^{75}$ Th. M. de Boer, Party Autonomy and Its Limitations in the Rome II Regulation, 9 YEARBOOK OF PRIVATE INTERNATIONAL LAW 22 (2007).
} 
(6) Occurrencing issue in the contract and tort, we should how to apply this principle and make its limitation?

\section{CONCLUSION}

It's been 11 years since China's accession into the WTO. Since then, China's profound reform, active effort to adapt to the trend of economic globalization and also opening up the Chinese economy has put China in a good position. With this in mind and that China have had more frequent international exchanges and agreements; as well as close contacts in the field of international contracts, the cross-border transactions disputes then occurred more in a variety of non-contractual disputes. For China to actively respond to this situation, the timely development of the LAL was crucial. The relationship for many foreign-related civil legal applications has to be set to make it clear that, the relationship between China in the civil law on foreign attitudes and strategies are shown, to effectively protect the legitimate interests of the Chinese natural persons and legal persons. This will ensure that, the relationship between China and the international community stays friendly and is maintained. However, when the China passed the LAL, there were some problems that were discovered. Some of these problems are not mature enough to consider the development of legal norms and can not all be effectively solved, including some of the missing issues, discrepancies, and so provided is not comprehensive enough. Therefore, from the above analysis, we can reach the following conclusions.

First of all, In the future, the legislation or changes in the process of China's choice of law when the non-contract obligation is allowed to make a clear choice in advance, so you can clearly apply the law and increase the predictability. Party autonomy has the potential to reduce legal risk by enabling parties to specify in advance the scope of their liability. ${ }^{76}$ In addition, China should make a clear requirement in the formal, which shall express the form and the parties will facilitate the application of the law. Thirdly, when applying the law of common residence, should avoid the conflict of mandatory rules in third party country, because the same requirements are found in the Rome II and should not infringe the rights of the third party. Last but not the least, in China, the principle of party autonomy will be applied to extend the scope of the non-contract obligation, but should deal with the difference of contract and non-contract obligation and define the limitations of different relationships within their respective legal relations.

\footnotetext{
${ }^{76}$ Tolek Petch, The Rome II Regulation: An Update, 21(8) J.I.B.L.R. 453 (2006).
} 